\title{
Tourism through the gaze of stakeholders: The case of Óbidos lagoon in Portugal
}

\begin{abstract}
Coastal lagoons are valued and sensitive ecosystems often threatened by human pressure. In our study we focused on the development of local activities in the Óbidos lagoon and we aimed to understand the stakeholders' view about the best solutions for local development. Stakeholders were divided into residents, tourists, groups of interest and surveys and interviews were applied. The results indicated that although the lagoon is considered a dynamic economical resource for the local economy communities, tourism was identified by all stakeholders as the strategic tool for development in the lagoon. These results suggest the urgency to promote sustainable guidelines for the local tourism development.
\end{abstract}

Keywords: sustainable tourism, Óbidos Lagoon, stakeholders, environment, management, cultural usages.

\section{Introduction}

Coastal lagoons are ecosystems of high biological productivity and regarded as important economic engines for the regional and national economic development. This economic significance has awaken a global awareness to its fragility and, consequently, to the necessity of its protection, conservation and sustainable management (Gamito, Gilabert, Marcos, \& Pérez-Ruzafa, 2005; Pérez-Ruzafa et al., 2000, 2002; PérezRuzafa, Marcos, \& Gilabert, 2005b).

Authors as Newton, A. et al, (2013) reinforce this idea stating that coastal lagoons are not only important ecological systems, but also have considerable historical and socioeconomic value. Despite that, these fragile systems still face serious threats by natural and human pressures.

Due to an uncontrolled growth of economic activities in the coastal zones and its perceived negative effects, it is necessary to consider how these regions can be regenerated, preserved and managed using a triple bottom line approach (TBL): economic, social and environmental (Elkington, 2004). A holistic sustainable management of the territory, based on the TBL concept, is often pointed as the solution to these places, mainly through sustainable tourism activities because of its direct dependence upon natural and cultural heritage resources (Dodds, 2007; Jamal \& Stronza, 2009; Jennings, 2004). Nevertheless, a sustainable management is only attained through a community-based management plan (Joppe, 1996; Stone \& 
Nyaupane, 2013). The stakeholder's involvement and collaboration as a starting point towards a sustainable development is an approach widely accepted and defended in the literature by numerous researchers (see Aas, Ladkin, \& Fletcher, 2005; Cooper, Scott, \& Baggio, 2009; Currie, Seaton, \& Wesley, 2009; d'Angella \& Go, 2009; Jamal \& Getz, 1995, 1999; Ladkin \& Bertramini, 2002; March \& Wilkinson, 2009; Ryan, 2002).

Óbidos lagoon is a semi-enclosed coastal Atlantic lagoon located 150km North of Lisbon, Portugal. Geographically delimited by the counties of Caldas da Rainha and Óbidos. It has about 6 kilometres of long, with a width between a thousand and a thousand and five hundred meters. For centuries, the populations settled on the coastline to take advantage of watersheds and nearness to the sea, developing propitious activities in the region like fishing, salt extraction, collecting maritime plants, maritime transport and commerce, port activities and naval construction (Serra, 1995, 2012; Silva, 1994).

[Figure 1. Óbidos lagoon map adapted from Malhadas et al., 2010.]

The bivalves harvesting and fishing activities represent the major or the only source of income to several families that live in the lagoon surroundings. This excessive economic dependence resulted in an unbalanced and uncontrolled development of harvesting and fishing activities what caused a decrease of various species and some are endangered such as the oysters (Parreira, 1999; Baptista, 2005).

This decrease resulted into serious economic disadvantages to families that relied directly on the lagoon to survive. Along with the harvesting activities the development of agricultural practices and food industries around the lagoon led to pressures, nutrient and organic matter input, fertilisers and input of contaminants, such as pesticides and herbicides that affected the bivalves many times and became unfit for human consumption (Parreira, 1999; Baptista, 2005).

Another revenue source of the lagoon is tourism. In the last decades the lagoon area became a tourist attraction for the sea and sun visitors. With the benefits of this industry some also negative facts came up as the high number of tourists particularly, during the summer, increasing domestic effluents and great pressure in the lagoon. Also the construction of urban areas, residential tourism, and golf courses contributed to high nutrient input into the lagoon which together with the agricultural practices and industry 
exploration around the lagoon led to its eutrophication, currently its main environmental issue (Parreira, 1999).

Tourism is also an economic activity that contributes to the local economies. Its main impacts in the lagoon are related to an increase of the domestic effluents and human pressure on the lagoon, particularly through the urbanization of the surroundings. This urbanization is very dissimilar once in the north side of the lagoon there is much more infrastructures prepared to receive tourists than in south side. For instance, while the north has toilets, picnic zones and caravan park available to tourists, the south remains more natural. These activities, together with golf courses, small industries and agriculture practices have been contributing to its eutrophication.

These were years of reckless practices and exploration of the Óbidos lagoon's natural resources, measures without an effective sustainable management plan for the ecosystem that revealed to be ruinous to this fragile system.

The aim of our study was to understand the stakeholders' view about the best solutions for local development once an effective planning and sustainable management is only possible to accomplish if the interests and visions of all the stakeholders are considered. To accomplish our aim in this study we divided the stakeholders in three distinct groups and then through different methods listened them all. The first group are the residents i.e. those who live in Caldas da Rainha and Óbidos counties. The second are the tourists i.e. those who visited the Óbidos lagoon. The third group is formed by a cluster that represents governmental organizations, educational institutions, nongovernmental organizations and businessmen.

\section{Methodology}

According to Aaker, Kumar and Day (2005:375) the non-probability sampling is typically applied in the exploratory stages of researching; with homogeneous populations; when the factor "operational ease" is required. Sometimes the nonprobability sampling research is more suitable or better than the probability sampling. A non-probability sampling research well led can produce faster and satisfactory results with fewer costs than a probability sampling (Aaker et al., 2005).

Therefore, from the convenience sampling method, the data were collected in two different stages; first we applied surveys personally to Caldas da Rainha and Óbidos's 
residents between 05 March and 03 May 2013 and then applied to tourists that visited the Óbidos lagoon between 11 June and 31 July 2013. A sample of 350 residents was determined using the most conservative estimate for a single proportion (0.5), a confidence level of $95 \%$ and a margin of error of $5.1 \%$. Once the tourist population is unknown, a sample of 350 tourists was taken to ensure a balanced comparative study.

All respondents were self-identified to be residents or tourists. This was verified through direct questioning by a researcher, to ensure the no occurrence of missing data, and thus guarantee $100 \%$ response rate. Only an appreciable amount of non-responses was reported (31\% for residents and 30\% for tourists), with regard to the question on monthly income (see Tables 2 and 4). This has a clear and obvious justification, supported by the fact there is always some reluctance of respondents to give this type of information.

The questionnaire was previous tested for clarity on a group of 30 residents and 27 tourists. After minor modifications, the final version of the questionnaire was ready for distribution.

The motivational items were identified and selected through careful study of existing scientific literature detailed on attitudes, perceptions and motivations (see Ribeiro et al., 2013; Manning et al., 2001; Silva et al., 2001). However, various adjustments were carried out to meet the aims of this research. Thus, for both questionnaires, first part included questions on socio-demographic characteristics and part two inquired about the degree of satisfaction and involvement of tourist and/or residents in the lagoon's activities. Particularly, for the residents' questionnaire a third part focused on perceptions towards the impacts of lagoon's activities in five relevant areas (namely, the region's economy, employment, environment and pollution, quality of life for residents and leisure activities and tourism). The questionnaire was developed in English, as well as in the local language (i.e., Portuguese).

All data collected were treated statistically with the statistical program SPSS (Statistical Package for the Social Sciences, 20 version). Due to the project goals we used the descriptive analysis and the Chi-square test for association in contingency tables (Steel et al., 1997). It is a statistical test commonly used to determine whether there is a significant association between the two variables according to a specific hypothesis. Therefore, it is thus possible to detect and describe patterns of association 
(or dissociation) between the various issues addressed throughout the two questionnaires. All results were considered statistically significant at the 5\% level (i.e., when p-value $<0.05)$.

In order to analyse qualitative data, we have applied two techniques of content analysis (Bardin, 2004). Content analysis is a qualitative analysis methodology based on text analysis (oral or written) produced by social actors (individual or collective). Using the CA methodology, we have previously defined a set of vectors (codes) that helped to reveal hidden meanings and social significance to agents' speech, according to a selective method of the information produced by those actors (Bardin, 2004). Thematic analysis is the predominant form of content analysis. It aims to reveal the social representations and the judgments of the interlocutors from an examination of certain components of their speech (Quivy, 1988). Some of the codes used to guide our interpretation of stakeholders' speech were: specific area of intervention, degree of inter-organizational solidarity, degree of protest, degree of creativity, perception of environmental risks, perception of social (dis)advantages at Óbidos lagoon, perception of economic problems and touristic opportunities at Óbidos lagoon. All the interviews were taken in the local language, Portuguese. The interviews were fully transcribed and the material was properly archived. Transcription took into account not only the verbal speech registration, but also the non-verbal speech (pauses, silences and emotional signs). All names were kept anonymous.

[Table 1. Interviews procedure]

\section{Results}

This chapter is divided into three parts: (1) the "Residents' Profile" that refers to the data collected through the questionnaires applied to residents; (2) the "Tourist's profile" addressed to the analysis of the collected data through the questionnaires applied to tourists; and finally, (3) the "stakeholders' vision" that refers to the data collected through interviews applied to stakeholders. 
A summary of the main socio-demographic characteristics of the residents analyzed is provided in table 2 . The results showed that $52 \%$ of the respondents are female; the majority of the respondents is between 25 and 64 years old and hold an elementary education level. The majority of the residents live in Caldas da Rainha. Most of the respondents are retired, unemployed or housewives. Additionally the most predominant income is less than 600 .

[Table 2. Residents' profile]

\section{Óbidos lagoon as leisure's spot}

The two counties where the Óbidos lagoon is located altogether sum an area bigger than $400.00 \mathrm{~km}^{2}$, therefore, not all of the residents use the lagoon as a leisure spot. Thus there is important to understand how the residents differ in their lagoon usage. According to the data collected the majority of the respondents stay near the Óbidos lagoon between 1 to 3 hours, then $38 \%$ of the respondents stay for 3 hours and the remaining $21 \%$ stay less than 1 hour. From the results $\left(\chi 2_{(2)}=17,5\right.$, p-value $=0,001$ $<0,05)$ we conclude that the residents that have practice activities more often at the lagoon and who usually take part in popular festivals around the lagoon have a closer relationship with the lagoon than the ones that not participate in any local festivity and consequently are the ones that spend more time near the lagoon.

The beach activities are the most popular among the respondents followed by walking and picnics. The beach activity is often practised by $38 \%$ of the respondents and sometimes by $40 \%$. Walking and picnics are occasional activities being practised by $50 \%$ of the respondents in "sometimes" mode. Examples of experiences that also recorded a significant result in "sometimes" mode are riding a bicycle, sport fishing and birdwatching.

We should underline the fact that $85 \%$ of the respondents have never practised aquatic motorized or non-aquatic motorised sports in the lagoon. The results allowed us to identify that the majority of the individuals involved in beach activities are also involved in picnics, walks and riding, all potential sustainable activities.

Regarding organized activities the most attractive events are the popular festivals. More than half of respondents stated that they have already taken part in Festa da Nossa 
Senhora do Bom Sucesso and then in Procissão das Velas and in Festa da Aldeia dos Pescadores.

\section{Óbidos lagoon's impact}

The local population links its quality of life with the Óbidos lagoon and recognizes its recreation and tourism potential. More than $80 \%$ respondents said that the lagoon is a dynamic resource to the local and regional tourism. Its economic impact is highlighted by $70 \%$ respondents, which recognize the lagoon's benefits to the regional economy. About 50\% refers the lagoon as locally very important to create employment.

On the other hand, the respondent's age influence their opinion about the lagoon's impact to create jobs. The individuals with the ages between 25-34 years and 45-54 years are who believe in the potential and conditions of the territory to create employment and wealth.

Most respondents are neutral or consider the lagoon free of pollution, as only $30 \%$ of the respondents consider the lagoon polluted. Regarding the respondent's availability to recommend a visit to Óbidos lagoon we verified that about $75 \%$ answered positively to this question. There were some respondents that highlighted the lagoon's pollution as a limitative factor to the visit recommended. The lagoon's recommendation is made by personal contact (73\%) and social network by facebook (11\%). In this investigation we tried to understand if the recommendation would be dependent of some kind of affective bond and, indeed, there is a clear dependence between the time spent in the lagoon by the individuals and its recommendation. These are the ones that spent more time at the lagoon and created deeper bonds with it, are the ones that have recommended it most.

\section{Óbidos lagoon as income source}

The Óbidos lagoon is still far from being an important income source to the regional inhabitants. In 350 respondents only $8 \%$, stated financial benefits from the lagoon's resources. The activities more often pointed out by this small group are the fishing and shellfish harvesting, then catering and ambulant trade with a seasonal feature. Other activities are also mentioned but with less significance as the Sailing school which explores sportive activities and the shellfish's purification activities. 
When questioned about the importance of building an educational and recreational centre in the lagoon the respondents expressed different views, being the individuals with less education who presented a major difficulty to recognize the project's added value.

The residents' opinion about the lagoon's impacts in varied fields as well as their perception about the level of pollution of the lagoon is provided in Table 3.

[Table 3. Residents' opinion about the lagoon's impacts at various levels and their perception about its pollution]

\section{Tourist's profile}

A summary of the main socio-demographic characteristics of the tourists analyzed is provided in table 4 . The results showed that $51 \%$ of the respondents are female; the majority of the respondents is between 25 and 64 years old, is married and Portuguese. Most of the Portuguese tourists live nearby the lagoon, i.e., a distance not superior of 110 kilometres. The majority of the respondents hold the high school level of education. Most respondents are retired, followed by students and the unemployed. Most respondents indicated having a monthly salary between 1000 to 1600 euros.

[Table 4. Tourists' profile]

\section{Characterization of visits to Óbidos lagoon}

More than $60 \%$ of the respondents had already visited the lagoon more than once and just 34\% did it for the first time. The Portuguese are who visit the lagoon the most and the foreigners are the most newcomers with exception to the English who had already repeated the visits to the lagoon. Although visitation of the lagoon takes place during all year $(28 \%)$, most tourists visit the lagoon during summer months (59\%).

The majority of the tourists, $68 \%$ of the respondents, stated that have known about the lagoon through information spread informally by friends and/or relatives. The internet follows as an important mean of communication rather employed by individuals with higher education; meanwhile the individuals with less education prefer to follow the advice of their close ones. 
More than half of the respondents claimed to stay more than 3 hours at the lagoon. On the other hand, the respondents who stayed less than 1 hour represent less than $10 \%$. As was confirmed by the residents and tourists, the time spent in the lagoon has an influence on the activities and in their global perception about that natural place. Tourists that spent more time at the lagoon, recognize that their experience could be improved if there were suitable facilities and infrastructures.

The lagoon offers a privileged place for families, $49 \%$ of the respondents who visited the lagoon did it with their relatives. The categories "friends or co-workers" and "partner" also recorded significant values.

\section{Motivations and leisure activities}

Following the assumption that motivations start, support and guide behaviour, we asked the respondents to identify the three main motivations to visit the Óbidos lagoon. The predominant motivation mentioned was the beach, followed by the landscape and finally quietness. Living together with relatives was also declared by some individuals.

To the tourists the more attractive activities are the beach, the walks and the picnics. The beach stands out regarding the remaining activities, once it is the main reason to visit the lagoon. The walks and picnics allow for landscape observation, the quietness experienced and the peace of mind identified respectively as the second and third motivation to visit the Óbidos lagoon. Other leisure activities as fishing, riding a bicycle and non-aquatic sports were also identified.

On the other hand, the practised leisure activities differ according to the respondent's nationality. The beach, the queen activity, is fairly spread by all the nationalities as well as the walks which are not exclusive of a single nationality. The picnics are specially elected by the French and Portuguese and fishing is almost exclusively practised by Portuguese. Off the record, some international tourists asked us about the Portuguese law regarding their access to the fishing activity at the lagoon.

\section{Experience at the lagoon}

Regarding the directions to get to the lagoon is worth notice, the high level of satisfaction: $68 \%$ answered being satisfied, $18 \%$ claimed indifference and $14 \%$ showed dissatisfaction. We also verified that just $26 \%$ of the respondents followed the lagoon's 
interpretative guide, in other words, the informative boards about the historic, natural and landscaping heritage available on the several trails.

Off the record, there were many complaints from the international tourists about the interpretative guide, once it was only available in the Portuguese language. The international tourists are the ones who more enjoyed this touristic activity. Hence they are the ones that give more value to the interpretative guide.

[Figure 2. Tourists looking at the interpretive guide. ]

We noticed that the nature-based tourism activities are not sufficiently explored, being critical to us to understand why that happens. Thus, under the demand view we tried to know if there is potential to create and develop an offer of nature-based tourism products. Therefore, we questioned the visitors and the tourists about their availability to pay for a guided activity led by specialised staff. About 39\% of the respondents assumed the desire of living that experience, then the remaining $61 \%$ did not show interest in such activity. The respondents who showed interest in practicing the mentioned activities were questioned about how much they would pay for the guided activity which resulted in a wide range of values that vary between 3 and 20 euros per person.

About $62 \%$ of the respondents recognize that their experience could be more satisfactory if the facilities and infrastructures available at the lagoon were more developed. $77 \%$ stand out the need for public toilets in the lagoon and $50 \%$ pointed out the inexistence of suitable zones to do picnics. Though, with less significance, the advantage of having a place to rent bicycles as well as outdoor fitness equipment to workout was mentioned.

To finish, the main characteristics and behaviours of the visitors are summed up in Table 5.

[Table 5. Portuguese vs foreigners visit behaviour] 


\section{The stakeholders' vision}

According to Freeman, stakeholder is "any group or individual who can Affect or is affected by the achievement of the organization's objectives" (Freeman \& McVea, 2001: 4). This seminal theoretical perspective includes all stakeholders in the organization including shareholders, creditors, employees, customers, suppliers, government institutions (local, national, etc.) competitors, business partnerships, groups of interest, etc. (Friedman \& Miles, 2006). The «stakeholder theory» had represented an important contribution to integrate ethics, responsibility and sustainability alongside with the traditional economic point of view and intends to engage, on a larger scale, managers and teaching. To that extent, we tried to identify a plethora of views: political, academic commercial, cultural and environmental.

By establishing a dichotomy between «primary» and «secondary» stakeholders, Clarkson (1995) refers the need to considerate a larger number of interlocutors that influence or are influenced by the organization. This is the case of the media or interest groups (lobbies) that have the skill to mobilize public opinion. In fact, we collected evidences that local and national newspapers had made some highlights and informed public opinion to the existence of some inertia and incapacity to develop a strategic planning to Óbidos lagoon.

The stakeholders' speech shows a strong ethical engagement and commitment around the Óbidos lagoon either by having developed different kind of studies or by showing their interest in seeking sustainable solutions. However, the actions developed by these organizations not always are applied or have the desired effect due to varied constraints. For example, according to the member of West Water Supply and Sanitation Monitoring, a group of experts developed a dossier justifying why Óbidos lagoon should be recognized as Regional Protected Area. However, as a result of institutional inertia the dossier is not yet in the hands of the competent authorities that have legal power to recognize the lagoon as Regional Protected Area.

Other example of constraint associated to the lack of cooperation between local powers is underlined by a local businessman "[The local rulers] are unable to cooperate. It seems that we are talking about two different countries, unable of cooperating». The local businessman also states another constraint, namely the lack of responsibility. "There are a lot of people in charge of the lagoon. Therefore it is easy to 
pass the buck... and say: I can't do anything because I depend on them and them... and the other one also covers masks himself behind this, everyone hide behind the other one and there is no cohesion between them (political authorities)».

In the environmental sphere stakeholders recognize that have been a gradual growth in the environment control which brought some benefits. An example of that is a lower pollution in the water. However, they also are aware that there is plenty to improve. In fact they are unanimous referring siltation, caused by the tide movements, as the most serious issue of the lagoon, which need to be solved immediately. The siltation is decreasing the water quantity of the lagoon which results in the ecosystem unbalance, i.e. loss of specific flora and fauna of the lagoon.

Among other social and economic issues the big economic dependence from the lagoon resources suffered by the local shellfish harvesters and fisherman it was underlined by the stakeholders. This is in perfect accordance to a member of a nongovernmental organization entitled Nostrum, which refers that: «It is a very serious human issue if the species disappear, the species diversity existent in the lagoon. There is here also a cost issue regarding the recovery and repopulation, with the reintroduction of disappeared species, with a link cost-benefit about the shores intervention». Indeed, this fact was also noticed by the survey applied to the residents.

The tourist activities identified with major potential of development in the region were birdwatching, non-pollutants aquatic sports, Eco Museum's construction and structured trails around the environment and ethnography. In the structured trails the importance of guides or monitors specialized with legal credentials it was underlined by the stakeholders.

Although there is not available any study referring the amount of the lagoon's visitors it is consensual between stakeholders that there should not be a set maximum number of visitors to the area. This opinion results of a mutual understanding that the nature-based tourism is not massive tourism. However, the need for distinct modalities of accesses in some areas specially the areas where live endangered species should be assured.

Stakeholders mentioned environmental education as a key factor to solve the current lagoon issues. According to a university professor from Sport Sciences School of Rio Maior, environmental education is a long-term process and should start in the very 
beginning at home with relatives but also at primary schools. "There are boards with information about the lagoon, with the aim of bringing culture to people, change their minds and ways to be in a different place. It is very hard to change the minds it is a process that should beginning in the schools immediately in the primary school. One measure that should be taken into consideration is school's visits to this space with the intention of providing education about the conservation of this place and ways of using the space».

Finally, a summary with the main issues of the Óbidos lagoon identified by stakeholders as well as the possible solutions is provided in Table 5.

[Table 6. Stakeholder's summed up ideas.]

\section{Discussion}

To reach a sustainable tourism and other sustainable activities in the lagoon territory it is necessary to understand clearly its current and future economic, social and environment impacts and addressing the needs of the stakeholders (Waligo, Clarke, and Hawkins, 2012). Researchers have recognized the importance of understanding the stakeholder's perspectives, a management plan that involves the stakeholders present a much broader vision than that held by the conventional power elites, furthermore the success or failure of a sustainable management process depends directly on the level of acceptance project by the stakeholders, level of their participation, level of economic benefits received and how equitably the economic benefits are distributed in the community (Reed, 1997; Sautter, 1999; Pollnac \& Pomeroy, 2005; Christie, 2005; Cristie et al., 2005; Imran Alam \& Beaumont, 2013). Therefore, in this study we took in account the different categories of stakeholders like the tourists, the local community and special interest groups reaching a holistic vision of their different perspectives on the lagoon issues.

In the residents' perception the Óbidos lagoon is a dynamic resource of the local and regional tourism, they recognize its economic impact in the region either as a wealthy creation or employment creation, even though just $8 \%$ rely on the lagoon as their livelihood. The majority is aware of the lagoon economic potential and is confident despite the benefits that the lagoon already guarantees there are still several fields of 
opportunities to explore. According to Pollnac et al., (2005) this perception of the benefits that they would achieve from an improved management of the lagoon is a great indicator to the sustainability of a management project. If they believe that project has positive impacts on their well-being, they will support and sustain the project activities in the future.

The lagoon's pollution is an issue clearly identified by the local community, although many have the opinion that the lagoon's pollution issue is not as serious as it was years ago. On the other hand, the stakeholders' vision about the lagoon environment issues were focused on another problem, for them the major issue in the lagoon is the siltation that is creating serious difficulties in the ecosystem balance, this unbalance will result in terrible losses in the ecosystem with negative impacts to the environment and social fields, however the lagoon pollution was also mentioned as a serious problem. According to Imran et al., (2013) stakeholders with environmentally sound behaviour are really important to areas with fragile environments, these stakeholders are the key to support the conservation of the lagoon, and, therefore, it is important to spread this environmental awareness and orientation also to the local community. To accomplish this goal it is important to educate the local community since the very beginning as one of the interviewees underlined: it is in the primary school that this process should begin.

Still in the environment's scope it is consensual between the stakeholders that there should not be set a maximum number of visitors in the lagoon territory. Nevertheless the free access to the beach areas should be restricted in the most fragile areas along with the areas where the endangered species live. In Italy, in the marine protected area of Torre Guaceto, they already employed this strategy. The area is divided in three zones with different levels of protection: primary or core area, integral protection zone, where only scientific research and environmental education are allowed; secondary area, divided into two zones, namely general and partial protection zones, where human economic activities as fishing and recreation are allowed (Petrosillo, Zurlini, Corilianò, Zaccarelli, \& Dadamo, 2006).

Although the residents' opinions regarding the benefits of an educative centre are not consensual, being the higher educated who recognize added value of this project, other studies see it as an important tool to achieve the conservation nature through the 
tourists. In agreement with Liu, Xiao, Li, and Pechacek (2012) and Peters and Hawkins (2008) the message from educational programmes about the local environment could increase the willingness to pay entrance fees in environmental protected areas as well as to result in a positive feedback to friends and relatives which is truly important, once visitors' satisfaction was found of major significance to extend the message of conservation.

Our results confirmed the power of the messages transmitted through word of mouth, once the majority of the visitors that visit the lagoon were advised by their friends or relatives to do it. Thus, it is particularly imperative to satisfy the visitors and change their opinion regarding the absence of suitable infrastructures and facilities offered by the lagoon. The main points to improve are the lack of public toilets on the south side of the lagoon area and the picnic areas that should be improved and increased. Along with the pollution issue perceived by the local community which is a deterrent of the lagoon's recommendation.

The maritime tourism and the nature-based tourism are activities little explored, but present great room for growth. We confirmed that $39 \%$ of the respondents are available to participate in nature-based tourism activities led by tourist guides in Óbidos lagoon. These individuals mentioned that the fair value to pay for such activity should be between 3 and 20 euros per person. There are a group of studies that corroborate this result, the tourists attracted to the nature and environment are willing to pay different kind of fees to get access to this to environmental areas. For instance, in Italy the tourists are willing to pay up to $5 €$ per day for benefiting recreational use of the maritime protected area; in China the tourists would have to pay a fee 3-10 times higher than the current fee of 30 Yuan if that results in significant improvements in the natural area, including the tourists infrastructures and facilities (Petrosillo et al., 2006; Peters et al., 2008; Reynisdottir, Song, \& Agrusa, 2008; Liu et al., 2012).

\section{Conclusion}

According to stakeholders' dominant view, the key to improve social and economic status of the local community is the development of sustainable tourism activities and the encouragement of traditional activities. 
It is clear that there is a favourable symbiosis between what the local community and the stakeholders think about the advantages of developing sustainable tourism activities around the lagoon, and the tourists' availability to experience nature-based activities in the lagoon. However, this sort of practice has not been implemented in the territory yet. Therefore, based on the stakeholders' insights we developed some guidelines that will help the sustainable development of the territory and consequently improve the local community quality of life.

The local powers should promote and invest in the nature-based tourism activities development. Once this segment has plenty room to grow and might play a fundamental role in the intermediate seasons, as a tool to smooth the seasonality and to diversify the local tourism offer as well as will value the local environmental heritage. The lagoon territory offers an uncountable number of nature-based opportunities to explore. But due to the lagoon ecosystem's richness, particularly the avifauna's richness, we underline the importance of supporting bird watching sites development.

The development of an Interpretative and Recreation Centre about the lagoon that eases the lagoons environment understanding will be an asset and will contribute to achieve, in a long-term period, to a sustainable development in the territory. The main activities of the centre will be: 1) undertake informative and interpretative activities to visitors; 2) develop routes and interpretive scenarios in the lagoon surroundings such as the "fishing art" route; 3) boost the traditional activities with a place dedicated to exhibits, and workshops about the local fishing arts and handicraft. There will be equally a place where the art pieces can be purchased; 4) undertake informative and educational activities with schools to promote between the youngsters an environmental awareness; 5) develop agreements of cooperation between universities and scientific organizations to control and monitoring the fauna and flora of the lagoon as well as the water quality of the lagoon; 6) control the free access in the areas where the endangered species live and collect information about the lagoon visitors and eliminate the current lack of information about how many people visit the lagoon.

Finally, the lagoon surroundings should be rehabilitated and then monitored providing basic equipment such as picnic areas and viewpoints that will attract the local community as well as tourists into the lagoon. 


\section{References}

Aaker, D., Kumar, V., \& Day, G. (2005). A pesquisa de Marketing [Marketing Research]. $2^{a}$ ed., São Paulo: Editora Atlas.

Aas, C., Ladkin, A., \& Fletcher, J. (2005). Stakeholder collaboration and heritage management. Annals of Tourism Research, 32 (1), 28-48.

Baptista, C. (2005). Faina na Lagoa: Os Pescadores e Mariscadores da Lagoa de Óbidos [Lagoon's harvesting: The fisherman and bivalves pickers of Óbidos Lagoon]. LeaderOeste, Cadaval. Fotografias de José de Deus Rodrigues.

Barbosa, P., G. (1991). Documentos, Lugares e Homens. Estudos de História Medieval. [Papers, Places and Men. Studies of Medieval History]. Lisboa, Edições Cosmos.

Bardin L., (1977). Análise de Conteúdo [Content Analysis]. Lisboa: Edições 70.

Bauer, M., \& Gaskell, G. (2000). Qualitative researching with text, image and sound: a practical handbook for social research, N.Y., Sage Publications.

Carvalho, M. (n.d.). Lagoa de Óbidos: Um paraíso em vias de desaparecimento [Óbidos Lagoon: An endangered paradise]. Retrieved from http://naturlink.sapo.pt/NaturSAPO/Artigos/content/Lagoa-de-obidos-um-paraiso-emvias-de-desaparecimento?bl=1\&viewall=true.

Christie P. (2005). Is Integrated Coastal Management Sustainable? Ocean \& Coastal Management 48, 208-232.

Christie P., Lowry K., White A. T., Oracion E. G., Sievanen L., Pomeroy R. S., ... Eisma R. V. (2005). Key findings from a multidisciplinary examination of integrated coastal management process sustainability. Ocean \& Coastal Management 48, 468-483. Cooper, C., Scott, N., \& Baggio, R. (2009). Network position and perceptions of destination stakeholder importance. An International Journal of Tourism and Hospitality Research, 20 (1), 33-45.

Currie, R. R., Seaton, S., \& Wesley, F. (2009). Determining stakeholders for feasibility analysis. Annals of Tourism Research, 36 (1), 41-63.

d'Angella, F., \& Go, F. M. (2009). Tale of two cities' collaborative tourism marketing: towards a theory of destination stakeholder assessment. Tourism Management, 30 (3), 429-440.

Dodds, R. (2007). Sustainable tourism and policy implementation: lessons from the case of Calvia, Spain. Current Issues in Tourism, 10 (1), 296-322.

Fortin, M., F. (1999). O processo de investigação: Da concepção à realização. [The research process: from designing to achievement]. Loures: Editora Lusociência, 205390.

Donaldson, T., \& Preston, L. (1995). "The Stakeholder Theory of the Corporation: Concepts, Evidence, and Implications", Academy of Management Review, January 1, 1995 vol. 20 in. 1 65-91.

Elkington, J. (1994). Towards the Sustainable Corporation: Win-Win-Win Business Strategies for Sustainable Development, California Management Review 36, no. 2: 90100.

Freedman, A., \& Miles, S. (2006). Stakeholders: Theory and Practice: Theory and Practice. New York: Oxford University Press.

Gamito, S., Gilabert, S., Marcos, C., \& Pérez-Ruzafa, A. (2005). Effects of changing environmental conditions on lagoon ecology. In Gönenç, I.E., Wolflin, J.P. (Eds.), Coastal Lagoons: Ecosystem Processes and Modeling for Sustainable Use and

Development (pp. 193-229).CRC Press, Boca Ratón, Florida. 
Henriques, V. (2005). Enquadramento Geográfico da Região de S. Martinho do Porto [Geographical framework of São Martinho do Porto's region]. In Edições Colibri/Associação Defesa Ambiente São Martinho do Porto (Eds.), A Baía de S. Martinho do Porto, Aspectos Geográficos e Históricos (pp.30-31) [São Martinho do Porto's bay, Geographical and Historical features]. Coord. de Maria Cândida Proença, Lisboa.

Imran S., Alam K., \& Beaumont N. (2013). Environmental orientations and environmental behaviour: Perceptions of protected area tourism stakeholders. Tourism Management 40, 290-299.

Jamal, T., \& Getz, D. (1995). Collaboration theory and community tourism planning. Annals of Tourism Research, 22 (1), 186-204.

Jamal, T., \& Getz, D. (1999). Community roundtables for tourism related conflicts: the dialects of consensus and process structures. Journal of Sustainable Tourism, 7 (3e4), 290-313.

Jamal, T., \& Stronza, A. (2009). Collaboration theory and tourism practice in protected areas: stakeholders, structuring and sustainability. Journal of Sustainable Tourism, 17 (2), 169-189.

Jennings, S. (2004). Coastal tourism and shoreline management. Annals of Tourism Research, 31 (4), 899-922.

Joppe, M. (1996). Sustainable community tourism development revisited. Tourism Management 17(7): 475-479.

Ladkin, A., \& Bertramini, A. M. (2002). Collaborative tourism planning: a case study of Cusco, Peru. Current Issues in Tourism, 5 (2), 71-93.

Liu C., Xiao W., Li J., \& Pechacek P. (2012). Attitude of tourists visiting nature reserves in China. Tourism Management Perspectives, 5, 1-4.

Malhadas, M., Leitão, P., Silva, A., Neves, R., (2009). Effect of coastal waves on sea level in Óbidos Lagoon, Portugal. Continental Shelf Research, 29, 1240-1250.

Manning, E.W., Clifford, G., Klaric, Z., \& Vereczi, G. (2001). Workshop on Sustainable Tourism Indicators for the Islands of the Mediterranean, Kukljica. Island of Ugljan, Croatia. 21-23 March, 2001. Final Report, Madrid: World Tourism Organization.

Martel, T. (1904). Relatório sobre o Caminho de Ferro das Caldas à Foz do Arelho e Iluminação elétrica das Caldas da Rainha. [Report about the rail train from Caldas da Rainha to Foz do Arelho and Caldas da Rainha's electric illumination]. Imprensa Africana, Lisboa.

March, R., \& Wilkinson, I. (2009). Conceptual tools for evaluating tourism partnerships. Tourism Management, 30 (3), 455-462.

Newton, A., Icely J., Cristina, S., Brito, A., Cardoso, A., Colijn, F., ... Zaldívar, J.M. (2013). An overview of ecological status, vulnerability and future perspectives of European large shallow, semi-enclosed coastal systems, lagoons and transitional waters, Estuarine. Coastal and Shelf Science, 140, 95-122. Retrieved from http://dx.doi.org/10.1016/j.ecss.2013.05.023.

Parreira, J. (1999). Lagoa de Óbidos: Património Ambiental [Óbidos Lagoon: Environmental Heritage]. Edição de Autor. Santos e Costa, Lda.

Parreira, J. (2002). A lagoa de Óbidos: Essencial Descobrir Óbidos [The Óbidos Lagoon: Essential to discover Óbidos]. Óbidos, Câmara Municipal de Óbidos e Associação de Defesa do Património do Concelho de Óbidos. 
Pérez-Ruzafa, A., Navarro, S., Barba, A., Marcos, C., Camara, M.A., Salas, F., \& Gutierrez, J.M. (2000). Presence of pesticides throughout trophic compartments of the food web in the Mar Menor lagoon (SE of Spain). Marine Pollution Bulletin 40 (2), 140-151.

Pérez-Ruzafa, A., Gilabert, J., Gutiérrez, J.M., Fernández, A.I., Marcos, C., \& Sabah, S., (2002). Evidence of a planktonic food web response to changes in nutrient input dynamics in the Mar Menor coastal lagoon, Spain. Hydrobiologia 475/476, 359-369.

Pérez-Ruzafa, A., Marcos, C., \& Gilabert, J. (2005b). The ecology of the Mar Menor coastal lagoon: a fast-changing ecosystem under human pressure. In Gönenç, I.E., Wolflin, J.P. (Eds.), Coastal Lagoons: Ecosystem Processes and Modeling for Sustainable Use and Development (pp. 392-422). CRC Press, Boca Ratón, Florida.

Peters H., \& Hawkins J. P. (2008). Access to marine parks: A comparative study in willingness to pay. Ocean \& Coastal Management, 52, 219-228.

Petrosillo I., Zurlini G., Corilianò M. E., Zaccarelli N., \& Dadamo M. (2006). Tourist perception of recreational environment and management in a marine protected area. Landscape and Urban Planning, 79, 29-37.

Pollnac R. B., \& Pomeroy R. S. (2005). Factors influencing the sustainability of integrated coastal management projects in the Philippines and Indonesia. Ocean \& Coastal Management 48, 233-251.

Quivy, R., \& Campenhoudt, L.V. (1988). Manuel de Recherche en Sciences Sociales [Handbook for Social Sciences Research]. Bordas, Paris.

Reed, M. G. (1997). Power Relations and Community-based Tourism Planning. Annals of Tourism Research 24 (3), 566-591.

Reynisdottir M., Song H., \& Agrusa J. (2008). Willingness to pay entrance fees to natural attractions: An Icelandic case study. Tourism Management, 29, 1076-1083.

Ribeiro, M. (1999). Stakeholders government-NGO Partnerships for international development: Portugal, a case-study, Lisboa, Cidac.

Ribeiro, M. Valle, P. \& Silva, J. (2013). Residents' Attitudes towards Tourism Development in Cape Verde Islands, Tourism Geographies: An International Journal of Tourism Space, Place and Environment, 15:4,654-679.

Ribeiro, O., Lautensach, H., \& Daveau, S. (1991). Geografia de Portugal: A Vida Económica e Social (Vol. 4). [Geography of Portugal: The Econmic and Social Life (Vol. 4)]. Lisboa, Edições João Sá da Costa.

Rodrigues, L., Tavares, M., \& Serra, J. (1993). Terra de Águas: Caldas da Rainha História e Cultura [Land of waters: Caldas da Rainha History and Heritage]. Câmara Municipal Caldas da Rainha.

Ryan, C. (2002). Equity, management, power sharing and sustainability-issues of the 'new tourism'. Tourism Management, 23 (1), 17-26.

Sautter, E. T. (1999). Managing Stakeholders a Tourism Planning Model. Annals of Tourism Research, 26 (2), 312-328.

Serra, J. (1995). Introdução à História das Caldas da Rainha: Cadernos de História Local [Introduction to Caldas da Rainha's History: Books of Local History]. Edição Património histórico - Grupo de Estudos, Caldas da Rainha. Gráfica da Ponte.

Serra, J. (2003). 21 anos pela História: Caldas da Rainha, estudos, notas e documentos [21 years by History: Caldas da Rainha, studies, notes, and documents]. Património histórico - Grupo de estudos, Caldas da Rainha. 
Serra, J. Apontamento histórico sobre a Lagoa de Óbidos: da Agricultura e Pesca ao Turismo [History note about Óbidos Lagoon: from Agriculture and Fishing to Toursim]. Retrieved from http://www.cidadeimaginaria.org/inv/Lagoa.htm.

Silva, J. (1964). A quinta da Foz: Foz do Arelho [The Foz's farm: Foz do Arelho]. Edição de autor, Lisboa.

Silva, J. (1988). A evolução da Lagoa de Óbidos nos últimos 120 anos (1867 a 1987) [The Óbidos Lagoon evolution in the last 120 years (1867 to 1987)]. Edição de autor, Lisboa.

Silva, J. (1988). As três lagoas: Pedreneira, Alfeizerão, e Óbidos. Que nos fins do neolítico existiam junto à costa atlântica desde Alpedriz até à Columbeira. [The three lagoons: Pedreneira, Alfeizerão, e Óbidos. Which in the late Neolithic existed together the Atlantic coast since Alpedriz until Columbeira] Edição de autor, Lisboa.

Silva, J. (1995). Campeonatos Nacionais de Remo de 1947: Realizados na Lagoa de Óbidos - Foz de Arelho [National Rowing Championships of 1947: Carried out in Óbidos Lagoon - Foz do Arelho]. Edição de autor, Lisboa.

Silva, J., Mendes, J., \& Guerreiro, M. (2001). Construcão de Indicadores de Avaliacão da Qualidade no Turismo [Design of indicators of quality evaluation].Lisboa: Projeto de Investigação da Universidade do Algarve, Direção Geral do Turismo.

Silva, M. (1994). A região de Óbidos na época medieval - Estudos [Óbidos region in medieval period - Studies]. Coleção P.H. - Estudos e Documentos, Caldas da Rainha.

Silva, M. (1994). O Concelho de Óbidos na Idade Média [The Óbidos County in the Middle Age]. Faculdade de Letras da Universidade de Lisboa, 2008. Centro de História da Universidade de Lisboa.

Stone, MT., Nyaupane, G. (2013). Rethinking community in community-based natural resource management. Community Development. 45 (1): 17-31.

Thompson, P. (1978). The voice of the past: oral history. Oxford: Oxford University Press.

Trancoso, V. (1994). Grandela e Foz do Arelho [Grandela and Foz do Arelho]. Cadernos de História Local, Caldas da Rainha: Património Histórico.

Trindade, J. (2001). Memórias Históricas e diferentes apontamentos, acerca das antiguidades de Óbidos desde o ano 308 antes de Jesus Cristo até ao presente, tirados dos Historiadores portugueses e espanhóis e manuscritos originais dos arquivos, de que se faz menção nestes apontamentos [Historic memories and different notes about Óbidos' antiques since the year 308 before Jesus Christ untill present, removed from portuguese and spanish Historians and original manuscripts of files mentioned in these notes]. Camara Municipal de Óbidos. Pré-impressão, Impressão e Acabamento. Elo Publicidade, Artes Gráficas, Lda.

Waligo V. M., Clarke J., Hawkins R., (2012). Implementing sustainable tourism: A multi-stakeholder involvement management framework. Tourism Management 36, 342353. 
Table 1. Interviews procedure

\begin{tabular}{ll}
\hline Interviews (11) & \\
\hline Gender & Male (8) \\
& Female (3) \\
Organizations & Governmental Organizations (3) \\
& Non-governmental Organizations (4) \\
& Educational Institutions(2) \\
& Businessmen (2) \\
\hline
\end{tabular}

Source: own construction.

Table 2. Residents' profile

\begin{tabular}{lll}
\hline Variables & Categories & Percentage (\%)
\end{tabular}




\begin{tabular}{|c|c|c|}
\hline \multirow[t]{2}{*}{ Gender } & Male & $48 \%$ \\
\hline & Female & $52 \%$ \\
\hline \multirow[t]{6}{*}{ Age } & $16-24$ & $12 \%$ \\
\hline & $25-34$ & $19 \%$ \\
\hline & $35-44$ & $18 \%$ \\
\hline & $45-54$ & $18 \%$ \\
\hline & $55-64$ & $15 \%$ \\
\hline & $>=65$ & $20 \%$ \\
\hline \multirow[t]{5}{*}{ Marital status } & Single & $35 \%$ \\
\hline & Married & $49 \%$ \\
\hline & Divorced & $7 \%$ \\
\hline & Widow & $6 \%$ \\
\hline & Consensual union & $3 \%$ \\
\hline \multirow[t]{3}{*}{ Place of birth } & Caldas da Rainha & $39 \%$ \\
\hline & Óbidos & $27 \%$ \\
\hline & Other counties & $34 \%$ \\
\hline \multirow[t]{3}{*}{ County of residence } & Caldas da Rainha & $61 \%$ \\
\hline & Óbidos & $37 \%$ \\
\hline & Outros & $2 \%$ \\
\hline \multirow[t]{2}{*}{ Residence } & $1^{\text {st }}$ residence & $97 \%$ \\
\hline & $2^{\text {nd }}$ residence & $3 \%$ \\
\hline \multirow[t]{3}{*}{ Education } & Elementary school & $44 \%$ \\
\hline & High school & $38 \%$ \\
\hline & University & $18 \%$ \\
\hline \multirow[t]{8}{*}{ Profession } & Retired & $22 \%$ \\
\hline & Unemployed & $13 \%$ \\
\hline & Housewife & $7 \%$ \\
\hline & Commercial & $6 \%$ \\
\hline & Student & $6 \%$ \\
\hline & Waiter & $3 \%$ \\
\hline & Fisherman & $3 \%$ \\
\hline & Others & $40 \%$ \\
\hline \multirow{5}{*}{$\begin{array}{l}\text { Monthly } \\
\text { values) }\end{array}$} & $<600 €$ & $34 \%$ \\
\hline & $600-1000 €$ & $21 \%$ \\
\hline & $1000-1600 €$ & $9 \%$ \\
\hline & $>1600 €$ & $4 \%$ \\
\hline & No answer & $31 \%$ \\
\hline
\end{tabular}

Source: Own construction 
Table 3. Residents' opinion about the lagoon's impacts at various levels and their perception about its pollution

\begin{tabular}{|c|c|c|c|c|c|c|c|c|}
\hline \multirow{2}{*}{$\begin{array}{l}\text { Fields } \\
\text { Lagoon's local } \\
\text { economic impact }\end{array}$} & \multicolumn{2}{|c|}{ Beneficial } & \multicolumn{2}{|c|}{$\begin{array}{l}\text { Neutral/ without } \\
\text { opinion }\end{array}$} & \multicolumn{2}{|c|}{ Harmful } & \multicolumn{2}{|l|}{ Total } \\
\hline & 245 & $(70 \%)$ & 85 & $(24 \%)$ & 20 & $(6 \%)$ & 350 & $(100 \%)$ \\
\hline $\begin{array}{l}\text { Lagoon's job } \\
\text { creation impact }\end{array}$ & 176 & $(50 \%)$ & 142 & $(41 \%)$ & 32 & $(9 \%)$ & 350 & $(100 \%)$ \\
\hline $\begin{array}{l}\text { Lagoon's quality } \\
\text { of life impact }\end{array}$ & 277 & $(79 \%)$ & 55 & $(16 \%)$ & 18 & $(5 \%)$ & 350 & $(100 \%)$ \\
\hline $\begin{array}{l}\text { Lagoon's tourism } \\
\text { activities impact }\end{array}$ & 308 & $(88 \%)$ & 37 & $(11 \%)$ & 5 & $(1 \%)$ & 350 & $(100 \%)$ \\
\hline $\begin{array}{l}\text { Development of } \\
\text { an educational and } \\
\text { recreational centre } \\
\text { about the lagoon }\end{array}$ & 295 & $(84 \%)$ & 47 & $(13 \%)$ & 8 & $(2 \%)$ & 350 & $(100 \%)$ \\
\hline Field & \multicolumn{2}{|c|}{ Non-polluted } & \multicolumn{2}{|c|}{$\begin{array}{l}\text { Neutral/ without } \\
\text { opinion }\end{array}$} & \multicolumn{2}{|c|}{ Polluted } & \multicolumn{2}{|c|}{ Total } \\
\hline $\begin{array}{l}\text { Lagoon's } \\
\text { pollution levels }\end{array}$ & 121 & $(35 \%)$ & 123 & $(35 \%)$ & 106 & $(30 \%)$ & 350 & $(100 \%)$ \\
\hline
\end{tabular}

Source: own construction. 
Table 4. Tourists' profile

\begin{tabular}{|c|c|c|}
\hline Variables & Categories & Percentage (\%) \\
\hline \multirow[t]{2}{*}{ Gender } & Male & $49 \%$ \\
\hline & Female & $51 \%$ \\
\hline \multirow[t]{6}{*}{ Age } & $16-24$ & $9 \%$ \\
\hline & $25-34$ & $22 \%$ \\
\hline & $35-44$ & $25 \%$ \\
\hline & $45-54$ & $23 \%$ \\
\hline & $55-64$ & $12 \%$ \\
\hline & $>=65$ & $9 \%$ \\
\hline \multirow[t]{5}{*}{ Marital status } & Single & $27 \%$ \\
\hline & Married & $61 \%$ \\
\hline & Divorced & $5 \%$ \\
\hline & Widow & $2 \%$ \\
\hline & Consensual union & $5 \%$ \\
\hline \multirow[t]{7}{*}{ Nationality } & Portuguese & $65 \%$ \\
\hline & English & $9 \%$ \\
\hline & French & $5 \%$ \\
\hline & Spanish & $4 \%$ \\
\hline & German & $3 \%$ \\
\hline & Dutch & $2 \%$ \\
\hline & Others & $12 \%$ \\
\hline \multirow[t]{3}{*}{ Education } & Elementary school & $19 \%$ \\
\hline & High school & $44 \%$ \\
\hline & University & $37 \%$ \\
\hline \multirow[t]{9}{*}{ Profession } & Retired & $14 \%$ \\
\hline & Student & $7 \%$ \\
\hline & Unemployed & $7 \%$ \\
\hline & Teacher & $6 \%$ \\
\hline & Engineer & $4 \%$ \\
\hline & Businessman & $3 \%$ \\
\hline & Nurse & $3 \%$ \\
\hline & Factory Worker & $3 \%$ \\
\hline & Others & $53 \%$ \\
\hline \multirow[t]{5}{*}{ Monthly income } & $<600 €$ & $10 \%$ \\
\hline & 600-1000€ & $20 \%$ \\
\hline & $1000-1600 €$ & $21 \%$ \\
\hline & $>1600 €$ & $19 \%$ \\
\hline & No answer & $30 \%$ \\
\hline
\end{tabular}

Source: Own construction. 
Table 5. Portuguese vs foreigners visit behaviour

\begin{tabular}{|c|c|c|c|c|c|}
\hline & $\mathrm{N}$ & $\begin{array}{l}\text { First time } \\
\text { Visiting }\end{array}$ & $\begin{array}{l}\text { Main } \\
\text { motivations }\end{array}$ & $\begin{array}{l}\text { Main } \\
\text { tourism } \\
\text { activities }\end{array}$ & Season \\
\hline Portuguese & $227 \quad(65 \%)$ & No & $\begin{array}{l}\text { Beach } \\
\text { Landscape } \\
\text { observation }\end{array}$ & $\begin{array}{l}\text { Beach } \\
\text { Picnics }\end{array}$ & Summer \\
\hline \multirow[t]{2}{*}{ Foreigners } & $123(35 \%)$ & Yes & $\begin{array}{l}\text { Beach } \\
\text { Landscape } \\
\text { observation }\end{array}$ & $\begin{array}{l}\text { Beach } \\
\text { Walking }\end{array}$ & Summer \\
\hline & $\begin{array}{l}\text { Known about } \\
\text { the Lagoon }\end{array}$ & With whom & $\begin{array}{l}\text { Mean of } \\
\text { transportation }\end{array}$ & Time & Experience \\
\hline Portuguese & $\begin{array}{ll}\text { Friends } & \text { and } \\
\text { relatives } & \end{array}$ & $\begin{array}{l}\text { Relatives } \\
\text { Friends and } \\
\text { co-workers }\end{array}$ & $\begin{array}{l}\text { Own/ friends/ } \\
\text { relatives vehicle } \\
\text { Auto caravan }\end{array}$ & $\begin{array}{l}\text { More than } 3 \\
\text { hours }\end{array}$ & $\begin{array}{l}\text { Improved with } \\
\text { infrastructures } \\
\text { and facilities }\end{array}$ \\
\hline Foreigners & $\begin{array}{l}\text { Friends and } \\
\text { relatives } \\
\text { Internet }\end{array}$ & $\begin{array}{l}\text { Relatives } \\
\text { Partner (wife/ } \\
\text { husband) }\end{array}$ & $\begin{array}{l}\text { Own/ friends/ } \\
\text { relatives vehicle } \\
\text { Rented vehicle }\end{array}$ & $\begin{array}{l}\text { More than } 3 \\
\text { hours }\end{array}$ & Excellent \\
\hline
\end{tabular}

Source: own construction.

Table 6. Stakeholder's summed up ideas.

\begin{tabular}{|c|c|c|}
\hline Fields & Issues & Solutions \\
\hline Environmental & $\begin{array}{l}\text { Siltation (eutrophication) } \\
\text { Ecosystem unbalance } \\
\text { Pollution } \\
\text { Loss of species }\end{array}$ & $\begin{array}{l}\text { Sustainable tourism activities } \\
\text { Environmental education } \\
\text { Balance between environment and business } \\
\text { activities } \\
\text { Define different access to the beach (protect } \\
\text { endangered species) }\end{array}$ \\
\hline Political & $\begin{array}{l}\text { Lack of cooperation } \\
\text { Institutional inertia }\end{array}$ & $\begin{array}{l}\text { Balance between environment and business } \\
\text { activities } \\
\text { Cooperation between local powers and local } \\
\text { stakeholders }\end{array}$ \\
\hline Economical & $\begin{array}{l}\text { Economic dependence } \\
\text { (harvesters/fisherman) } \\
\text { Human investment inexistence }\end{array}$ & Sustainable tourism activities \\
\hline Social & Local community ageing & $\begin{array}{l}\text { Sustainable tourism activities } \\
\text { Environmental education (primary school) }\end{array}$ \\
\hline
\end{tabular}

Source: own construction. 
Figure 1. Óbidos lagoon map adapted from Malhadas et al., 2010

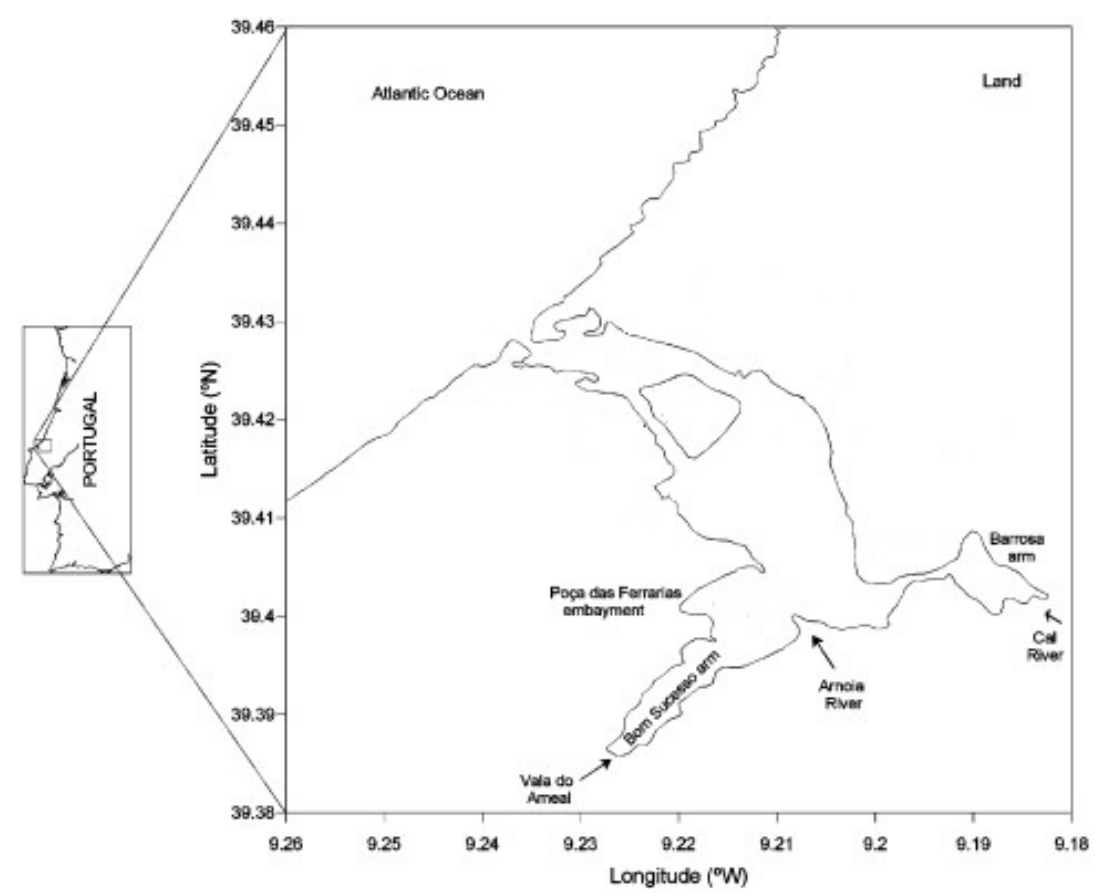

Figure 2. Tourists looking at the interpretive guide

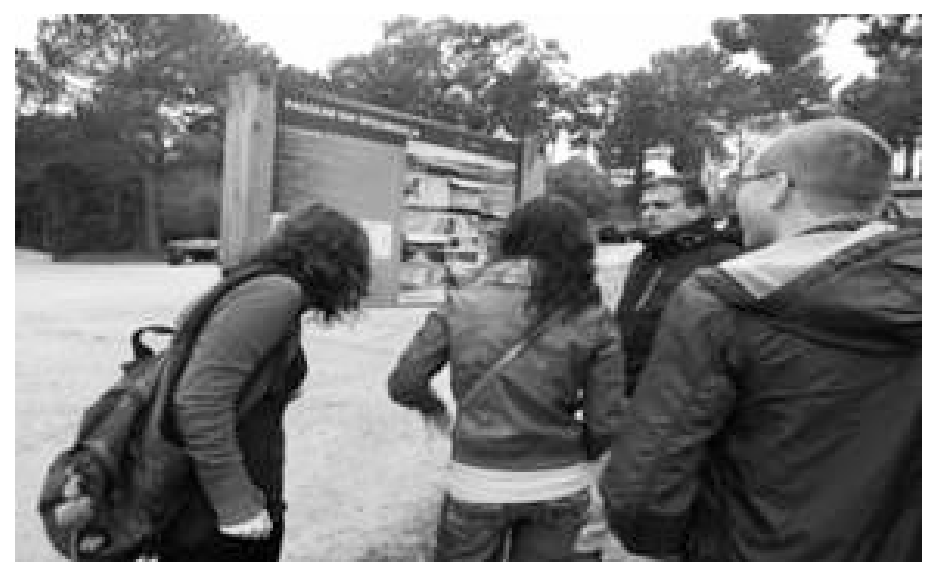

Source: Own. 